\title{
PERANCANGAN PRODUK TAS TRAVEL MULTIFUNGSI DENGAN MENGGUNAKAN METODE QUALITY FUNCTION DEPLOYMENT (QFD)
}

\author{
Chalis Fajri Hasibuan ${ }^{1}$, Sutrisno ${ }^{2}$ \\ ${ }^{1,2}$ Fakultas Teknik, Program Studi Teknik Industri, Universitas Medan Area \\ Jl. Kolam, No 1 Medan Estate \\ Email : chalisfajri@yahoo.co.id
}

\begin{abstract}
Abstrak. Tas travel merupakan sarana penyimpanan barang yang sangat penting bagi seorang dalam melakukan suatu perjalanan apalagi professional yang dalam pekerjaan saring berpindah dengan berbagai perlengkapan yang harus disiapkan. Lebih dari $85 \%$ orang Indonesia melakukan perjalanan internasional dan nasional untuk bersantai sedangkan selebihnya untuk urusan bisnis ataupun pendidikan. melihat peningkatan yang cukup besar maka penelitian ini bertujuan untuk melakukan perancangan tas travel yang multifungsi untuk mempermudah masyarakat yang melakukan perjalan sehingga penggunaan tas travel lebih optimal. Penelitian ini menggunakan metode perancangan produk yaitu Quality Function Deployment (QFD). Hasil karakteristik Perancangan Tas Travel yaitu Bentuk tas travel persegi panjang, Bentuk gagang tas travel persegi panjang, Warna tas travel biru dan merah bata, Ukuran tas travel dimana panjang 51 dan lebar $26 \mathrm{~cm}$, Tinggi gagang tas travel $45 \mathrm{~cm}$, Tinggi badan tas travel $43 \mathrm{~cm}$, Hiasan/motif pada tas travel polos, Bahan tas travel polimer Bahan gagang tas travel plastic, Bahan roda tas travel aluminium steel, Fungsi tambahan pada tas travel adalah tempat minum dan jas hujan
\end{abstract}

Keywords: Perjalanan, Tas Travel, Perancangan Produk, QFD

\section{Pendahuluan}

Era globalisasi yang semakin cepat mengharuskan orang untuk dapat berpindah secara cepat, dengan berpindah secara cepat mengharuskan memiliki tas travel yang dapat memuat segala keperluan dan kefleksibelan dalam penggunaan tas tersebut. Visa Global Travel Intentions Study 2015 menyatakan, masyarakat Indonesia diperkirakan akan melakukan rata-rata lima perjalanan dalam dua tahun ke depan, atau lebih banyak dari rata-rata global yaitu tiga perjalanan.

Orang Indonesia yang melakukan perjalanan ke luar negeri lebih banyak untuk bersantai. Sebanyak 85 persen responden Indonesia pada penelitian ini telah melakukan perjalanan internasional untuk bersantai dalam dua tahun terakhir. Angka ini lebih tinggi dibandingkan Global Travel Intentions Study 2013, di mana hanya 52 persen penduduk Indonesia telah melakukan perjalanan ke luar negeri untuk liburan. "Singapura dan Malaysia tetap menjadi negara tujuan utama bagi orang Indonesia. Namun bepergian ke Asia Utara, terutama ke Jepang, Hong Kong dan Korea, semakin popular. Salah satu yang paling berperan penting dalam perjalan adalah tas travel, Tas merupakan suatu sarana tempat menyimpan barang-barang baik untuk waktu sementara maupun dalam waktu yang cukup lama. Desain dan mode silih berganti, harga pun bervariasi. Desain selalu berkaitan dengan pengembangan ide dan gagasan, pengembangan teknik, proses produksi serta peningkatan pasar. (Devy, 2012).

Perwitasari (2007) mengidentifikasikan bahwa ada lima faktor utama yang dipentingkan pelanggan tas wanita, yaitu : bahan, model, ukuran, harga dan fungsi. Selanjutnya dengan menggunakan HOQ didapat atribut yang diprioritaskan, yaitu : bahan tas terbuat dari kulit, model tas adalah tas kerja, ukuran tas besar untuk menampung perlengkapan kerja.

Tas dapat memberikan semangat dan percaya diri bagi pemakainya. Demikian juga sebuah tas travel merupakan sarana penyimpanan barang yang sangat penting bagi seseorang dalam melakukan suatu perjalanan apalagi professional (model, pramugari, pilot, dll) yang dalam pekerjaannya sering berpindah dengan berbagai perlengkapan yang harus disiapkan. Biasanya pandangan kita pada sebuah tas travel adalah bentuknya yang kotak, kaku dan kurang cocok untuk digunakan selain hanya untuk bepergian. Sesungguhnya yang diperlukan adalah tas travel multi fungsi dengan disain modis dan ergonomis untuk berbagai aktivitas (Sukania, 2009).

Melihat dari latar belakang yang ada sehingga penelitian ini bertujuan untuk melakukan 
perancangan tas travel yang multifungsi berdasarkan metode quality function deployment (QFD).

\section{Metode Penelitian}

\subsection{Lokasi Penelitian}

Penelitian perancangan produk tas travel multifungsi dilakukan di Kota Medan, karena kota medan merupakan kota metropolitan yang masyarakatnya banyak melakukan perjalanan.

\subsection{Populasi dan Sample}

Populasi adalah keseluruhan karakteristik atau sifat yang dimiliki objek (Sugiyono, 2004). Populasi dalam penelitian ini adalah pengguna tas travel dalam hal ini anak-anak umur 15-22 tahun yang telah menggunakan tas travel dengan jumlah sampel minimal 30 orang. Sampel adalah sebagian dari jumlah dan karakteristik yang dimiliki oleh populasi (Sugiyono, 2004). Sampel pada penelitian ini adalah pengguna tas travel di kota Medan.

\subsection{Blok Diagram Penelitian}

Penelitian ini memiliki blok diagram sebagai berikut

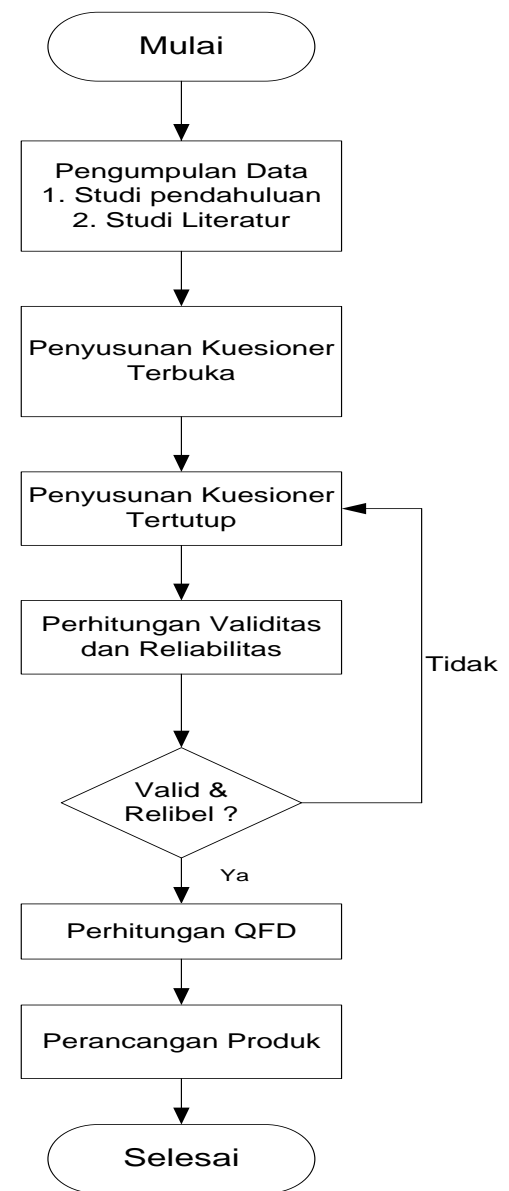

Gambar 1. Blok Diagram Penelitian

\section{Hasil dan Pembahasan}

\subsection{Penilaian Kuesioner Terbuka}

Kuesioner terbuka dibuat dengan tujuan untuk mengetahui spesifikasi-spesifikasi produk yang diinginkan oleh konsumen. Pertanyaan yang diajukan pada kuesioner terbuka jawabannya bersifat bebas, tidak ada batasan untuk menjawab sesuai dengan keinginan yang dipikirkan oleh konsumen. Jawaban yang diperoleh dari pengajuan kuesioner terbuka ini adalah dasar untuk pengajuan kuesioner tertutup yang akan dilakukan kemudian. Modus dari setiap pertanyaan yang terdapat pada hasil kuesioner terbuka akan menjadi atribut yang akan ditanyakan pada kuesioner tertutup. Hasil kuesioner terbuka dapat dilihat pada tabel 1.

Tabel 1. Rekapitulasi Kuesioner Terbuka

\begin{tabular}{|c|c|c|}
\hline Kriteria & $\begin{array}{c}\text { Hasil } \\
\text { Kuesioner }\end{array}$ & $\begin{array}{c}\text { Responden } \\
\text { Yang Memilih }\end{array}$ \\
\hline Bentuk Tas & Persegi Panjang & 9 \\
\hline $\begin{array}{c}\text { Bentuk Gagang } \\
\text { Tas }\end{array}$ & Persegi Panjang & 12 \\
\hline Warna Tas & $\begin{array}{c}\text { Biru Muda \& } \\
\text { Merah Bata }\end{array}$ & 6 \\
\hline $\begin{array}{c}\text { P \& L } \\
\text { Keseluruhan Tas }\end{array}$ & $51 \times 26 \mathrm{~cm}$ \\
\hline $\begin{array}{c}\text { Tinggi Gagang } \\
\text { Tas }\end{array}$ & $45 \mathrm{~cm}$ & 6 \\
\hline Tinggi Badan Tas & $43 \mathrm{~cm}$ & 12 \\
\hline Hiasan/Motif & Polos & 9 \\
\hline Bahan Tas & Polimer & 7 \\
\hline $\begin{array}{c}\text { Bahan Gagang } \\
\text { Tas }\end{array}$ & Plastik & 11 \\
\hline $\begin{array}{c}\text { Bahan Roda } \\
\text { Steel }\end{array}$ & $\begin{array}{c}\text { Jas } \\
\text { Minum }\end{array}$ & 15 \\
\hline $\begin{array}{c}\text { Fungsi Tambahan } \\
\text { Hujaninium }\end{array}$ & \\
\hline
\end{tabular}

\subsection{Hasil Kuesioner Tertutup}

Berdasarkan hasil kuesinoer terbuka dibuatlah kuesioner tertutup dimana hasilnya akan dilakukan uji validitas dan reliabilitas, dalam hal ini pengujian relibilitas dan validitas akan dilakukan dengan menggunakan bantuan software SPSS. Hasil validitas dan reliabilitas dapat dilihat pada tabel 2 .

Tabel 2. Validitas dan Reliabilitas Produk

Utama

\begin{tabular}{|l|l|l|l|}
\hline \multicolumn{3}{|c|}{ Validitas } & Reliabilitas \\
\hline & Total & R tabel & $\begin{array}{l}\text { Cronbach's } \\
\text { Alpha }\end{array}$ \\
\hline Pertanyaan1 & $.475^{* *}$ & 0.361 & \\
\cline { 1 - 2 } Pertanyaan2 & .362 & 0.361 & .706 \\
\cline { 1 - 2 } Pertanyaan3 & $.433^{*}$ & 0.361 & \\
\hline
\end{tabular}


Tabel 2. Validitas dan Reliabilitas Produk Utama (Lanjutan)

\begin{tabular}{|l|l|l|l|}
\hline \multicolumn{3}{|c|}{ Validitas } & Reliabilitas \\
\hline & Total & R tabel & $\begin{array}{l}\text { Cronbach's } \\
\text { Alpha }\end{array}$ \\
\hline Pertanyaan4 & $.605^{* *}$ & 0.361 & \\
\hline Pertanyaan5 & $.588^{* *}$ & 0.361 & \\
\hline Pertanyaan6 & $.465^{* *}$ & 0.361 & \\
\hline Pertanyaan7 & $.634^{* *}$ & 0.361 & \multirow{2}{*}{.706} \\
\hline Pertanyaan8 & $.442^{*}$ & 0.361 & \multirow{2}{*}{} \\
\hline Pertanyaan9 & $.404^{*}$ & 0.361 & \\
\hline Pertanyaan10 & $.511^{* *}$ & 0.361 & \\
\hline Pertanyaan11 & $.492^{* *}$ & 0.361 & \\
\hline
\end{tabular}

Dari hasil dapat dilihat bahwa seluruh pertanyaan untuk produk utama sudah valid dan reliable.

\subsection{Penyusunan Quality Function Deployment (QFD)}

Langkah-langkah quality function deployment (QFD) dengan menggunakan matriks House of Quality adalah sebagai berikut.

1. Mengidentifikasi Keinginan Konsumen Ke dalam Atribut-atribut Produk

Untuk mengetahui keinginan konsumen terhadap produk tas travel maka dalam pengumpulan data dikumpulkan dalam 2 tahap yaitu kuesioner terbuka dan kuesioner tertutup.

2. Menentukan Tingkat Kepentingan Relatif dari Atribut Produk

Penentuan tingkat kepentingan relative atribut ini dilakukan dengan memberikan bobot pada masing-masing atribut dengan menggunakan skala prioritas yang didapat dari kuesioner tertutup.

3. Mengevaluasi Atribut Produk Pesaing Yang Sejenis

Tingkat kepentingan atribut dan pesaing yang diperoleh dari pengumpulan data kuesioner

4. Menggambarkan matrix perlawanan antara atribut produk dengan karakteristik teknik.

Atribut yang telah diterjemahkan kedalam karakteristik teknik diletakkan pada bagian vertical di tepi sebelah kiri sedangkan karakteristik teknik dibagian horizontal tepi atas

5. Mengidentifikasi hubungan antara atribut produk dengan karakkteristik teknik

Dalam hal ini dilakukan dengan menggunakan skor yang tertinggi menunjukkan tingkat kemudahan yang paling tinggi bagi tim perancang untuk mengidentifikasi karakteristik teknik yang paling mempengaruhi kepuasan konsumen.

6. Mengidentifikasi hubungan antara sesama karakteristik teknik

Langkah ini bertujuan untuk mengidentifikasi hubungan antara sesama karakteristik yang satu dengan yang lainnya

7. Menetukan target pencapaian untuk setiap karakteristik teknik

Selanjutnya, dapat digunakan House of Quality (HOQ) yang merupakan gabungan semua karakteristik teknik, atribut yang diinginkan konsumen, posisi produk pesaing dan produk utama terhadap atribut yang sama. Semuanya dibuat dalam rumah mutu dengan menggunakan metode QFD 


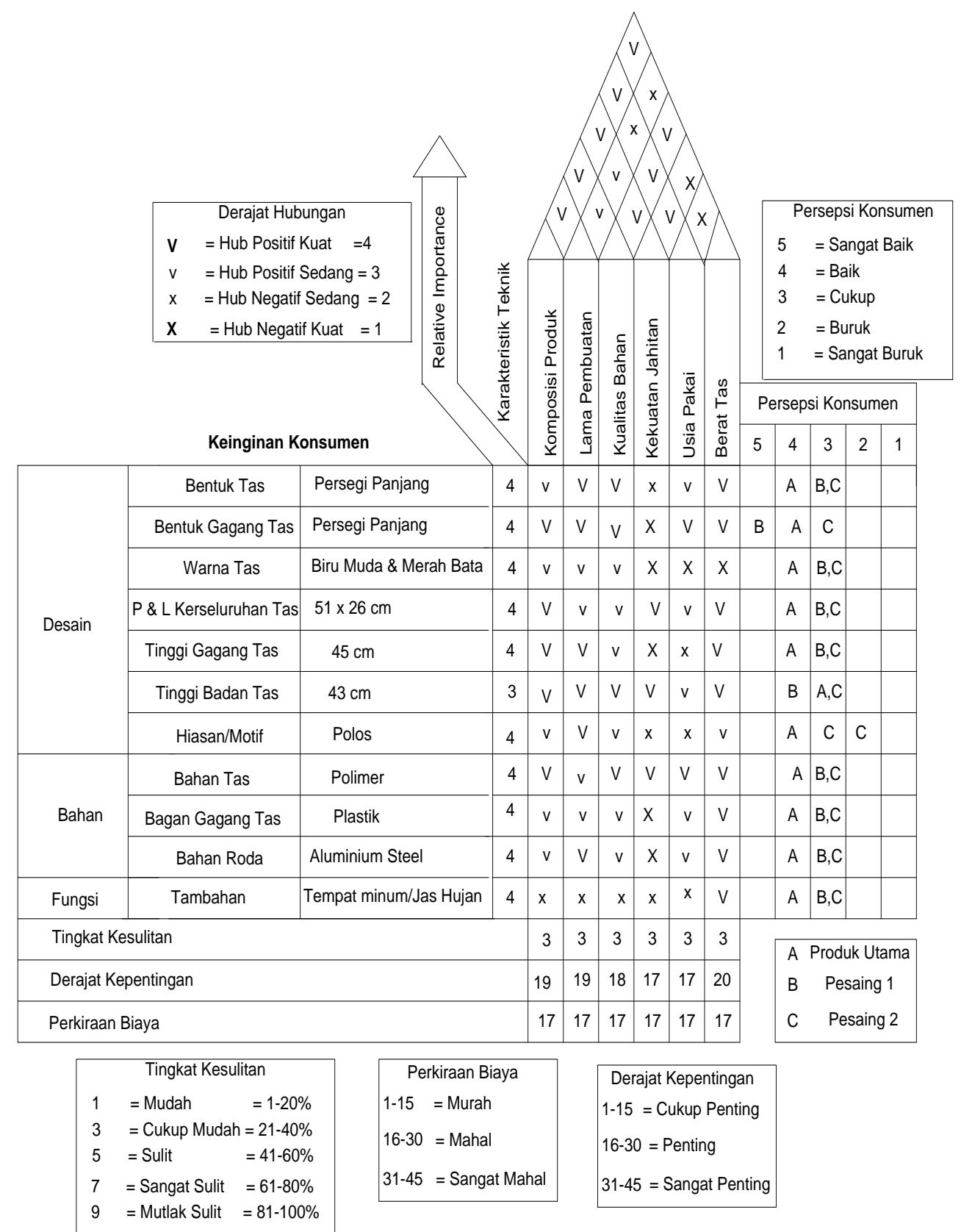

\section{Gambar 2. Quality Function Development (QFD) Produk Tas Travel}

Hasil dari QFD yang dilakukan

1. Atribut tas travel dari hasil qfd adalah sebagai berikut

a. Bentuk tas travel persegi panjang

b. Bentuk gagang tas travel persegi panjang

c. Warna tas travel biru dan merah bata

d. Ukuran tas travel dimana panjang 51 dan lebar $26 \mathrm{~cm}$

e. Tinggi gagang tas travel $45 \mathrm{~cm}$

f. Tinggi badan tas travel $43 \mathrm{~cm}$

g. Hiasan/motif pada tas travel polos

h. Bahan tas travel polimer

i. Bahan gagang tas travel plastic

j. Bahan roda tas travel aluminium steel

k. Fungsi tambahan pada tas travel adalah tempat minum dan jas hujan.
2. Perbandingan produk utama hasil penyebaran kuesioner dengan produk dari pesaing pada atribut yang sama adalah.

a. Untuk bentuk tas produk utama lebih unggul dari pada produk rancangan pesaing 1 dan 2

b. Untuk bentuk gagang tas produk pesaing 1 lebih unggul dari pada produk utama dan produk pesaing 2

c. Warna tas produk utama lebih unggul dripada perancangan produk pesaing 1 dan 2

d. Panjang dan lebar produk utama lebih unggul dripada perancangan produk pesaing 1 dan 2 
e. Tinggi gagang tas produk utama lebih unggul dripada perancangan produk pesaing 1 dan 2

f. Tinggi badan tas produk pesaing 2 lebih unggul daripada produk utama dan pesaing 1

g. Hisan/motif tas produk utama lebih unggul dripada perancangan produk pesaing 1 dan 2

h. Bahan tas produk utama lebih unggul dripada perancangan produk pesaing $1 \mathrm{dan}$ 2

i. Bahan gagang tas produk utama lebih unggul dripada perancangan produk pesaing 1 dan 2

j. Bahan roda tas produk utama lebih unggul dripada perancangan produk pesaing 1 dan 2

k. Fungsi tambahan tas produk utama lebih unggul dripada perancangan produk pesaing 1 dan 2 .

3. Tingkat Kesulitan. Semua karakteristik teknik tersebut cukup mudah untuk dikerjakan

4. Tingkat kepentingan semua karakteristik teknik tergolong penting kecuali kekuatan jahitan yang cukup penting

5. Perkiraan biaya. Perkiraan biaya dari produk rancangan tergolong dalam kategori mahal.

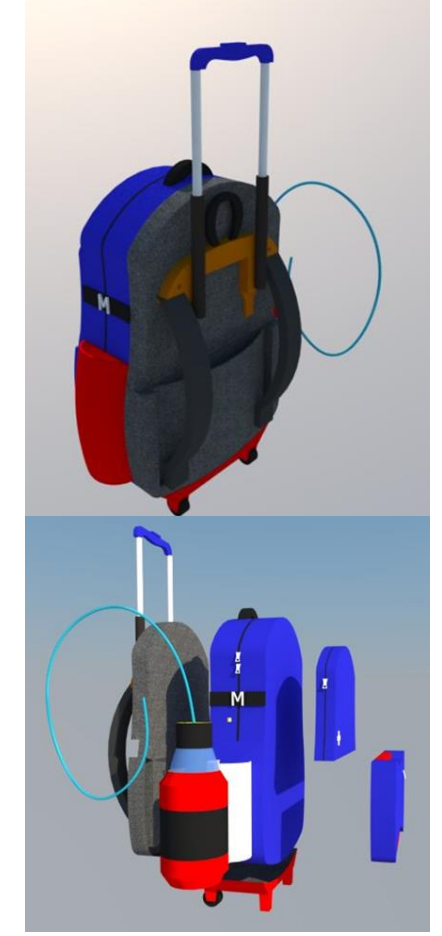

Gambar 3. Rancangan Produk

\section{Kesimpulan}

Dari hasil penelitian dapat dihasilkan kesimpulan yaitu:

1. Produk yang dihasilkan sudah sesuai dengan keinginan konsumen.

2. Produk yang dihasilkan lebih unggul dibandingkan dengan produk pesaing

3. Tingkat Kesulitan. Semua karakteristik teknik tersebut cukup mudah untuk dikerjakan

4. Tingkat kepentingan semua karakteristik teknik tergolong penting kecuali kekuatan jahitan yang cukup penting

5. Perkiraan biaya. Perkiraan biaya dari produk rancangan tergolong dalam kategori mahal.

\section{DAFTAR PUSTAKA}

Devy, D.S. 2012 Perancangan Tas Ransel Laptop Multifungsi Menggunakan Metode Rasional, Dokumen Tugas Akhir, Program Studi Teknik Industri - S1 | Fakultas Teknik | Universitas Dian Nuswantoro Semarang

Perwitasari. 2007. Rancangan Tas Wanita Dengan

Pendekatan Metode Quality Function Deployment (QFD) Untuk Memenuhi Suatu Segmen Pasar (Studi Kasus Pada Cv H.M. Choiri, Sido.Rjo). http://digilib.its.ac.id

Sugiyono. 2004. Statistik untuk Penelitian. Bandung : Alfabet.

Sukania, W, 2009. Perancangan Tas Ergonomis. Prosiding Seminar Nasional Ergonomi IX ISBN : 978-979-704-802-0. 